\title{
CALCULATION OF BLAST FURNACE SLAGS AS PRAC- 'TISED IN CERTAIN WORKS IN EUROPE.
}

By Auguste J. Rossi, C. E.

In another paper (this journal, Vol. 12, 6, 7) we have described a practical method of calculating the charges of a blast furnace $\mathrm{m}$ order to obtain a slag of a given type, which does not require the use of any formula or chemical symbol. It may be interesting to compare it with the method followed in certain works, in Eastern France, to arrive at the same result.

What is called "a charge" is this certain weight of ore, limestone and fuel, in relative proportion to each other, which are charged in a furnace at regular intervals of time during twentyfour hours. Technically, it is more properly the calculated weights of the relative qualities of limestone and ore necessary to obtain a given composition of slag, the quantity of fuel per ton of iron smelted, or per charge, being, as a rule, a factor which is assumed and which practice has taught, but subject to ulterior corrections as may be required.

The coal is supplied to furnish, by its combustion, the heat and the elements necessary for the chemical reactions which take place and only its ash contributes to the ultimate composition of the slag. In France, the charge is called "lit de fusion," an expression, it seems to us, having a more appropriate meaning than the vague term "charge." The total amount of ore and stone constitutes "a lit de fusion," "a charge," with an assumed quantity of fuel and the proportion of the two materials, ore and stone, are the elements to be calculated, bearing in mind the character of the slag desired as indicative of a special grade of pig iron and the percentage of ash of the fuel and its composition. 


\section{Calculation of a Shag a' The Works $\mathrm{X}$.}

The formula of the slag expected wh that of a "SeisguloSilicate" (monosilicate of Percy), $3 \mathrm{BO}, \mathrm{SiO}_{3}$ or $2 \mathrm{RO}, \mathrm{SiO}_{2}$ (orthosilicate, bibasic slag); oxygen of acid=oxygen of hase.

Two different kinds of ore were used, of which the composition is given below, the calculations being based on the determination of the fiee oxygen in the materials, demand a certain technical knowledge.

\section{1.-Gangue of Ore A.}

$\mathrm{SiO}_{8} 8.50$ Equiv. $\mathrm{SiO}_{3}=45.3 .$. Oxygen of $\mathrm{SiO}_{3}=8.50 \times \frac{24}{45.3}=\ldots .4 .50$

$$
\begin{aligned}
& \mathrm{Al}_{2} \mathrm{O}_{3} 5.50 \quad \because \quad \mathrm{Al}_{2} \mathrm{O}_{3}=51.5 \ldots \quad " \quad \mathrm{Al}_{2} \mathrm{O}_{8}=5.50 \times \frac{24}{24.5}=2.56 \\
& \left.\mathrm{CaO} 5.00 \text { " } \mathrm{CaO}=28 . \ldots \quad \text { ". } \mathrm{CaO}=7 . \quad \times \frac{8}{98}=1.43\right\} 4.40 \\
& \mathrm{MgO} 0.90 \quad \text { " } \mathrm{MgO}=20 .-\quad \cdots \quad \mathrm{MgO}=0.9 \times-200.31
\end{aligned}
$$

\section{D.-Gangue of Ore $B$.}

$\left.\mathrm{SiO}_{3} 29.5\right)$ on an average $\left(\mathrm{SiO}_{3} ; 25.00 \ldots\right.$ of $\mathrm{Acid} \mathrm{SiO}{ }_{3} 1.3 .24$

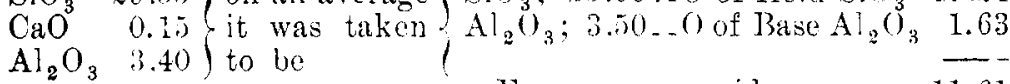

Free oxygen, acid ......... 11.61

$$
\text { 2. - Ash of Coil. }
$$

$$
\begin{aligned}
& \mathrm{SiO}_{3}=4.8 .80 \\
& \mathrm{Al}_{2} \mathrm{O}_{3}=33.00 \\
& \mathrm{CaO}=6.00 \\
& \mathrm{MgO}=3.20
\end{aligned}
$$

$$
\begin{aligned}
& \mathrm{S}_{1} \mathrm{O}_{3}=2.50 \\
& \mathrm{Al}_{2} \mathrm{O}_{3}=2.00 \\
& \mathrm{CaO}=52.50
\end{aligned}
$$

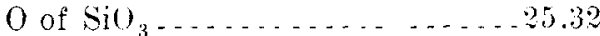

$$
\begin{aligned}
& \because \mathrm{Al}_{2} \mathrm{O} \mathrm{O}_{3} \ldots \ldots . \ldots 15.35 \text {; } \\
& \because \mathrm{CaO} \ldots \ldots \ldots 1.21\} \quad 18.36 \\
& \because \quad \lg (0 \ldots \ldots \ldots 1.28 \\
& \text { Fieo oxygen, acid ...... } 0.90
\end{aligned}
$$$$
\text { 4.-Limestone. }
$$

$$
\begin{aligned}
& \text { () of } \mathrm{SiO}_{3}=\ldots \ldots \ldots \ldots \ldots \ldots \ldots \ldots \\
& \because A]_{3}=\ldots \ldots 1.10 \text { ) } \\
& \because \mathrm{CaO}=\ldots . .15 .00\}
\end{aligned}
$$

Free oxygen, basic.......14.is

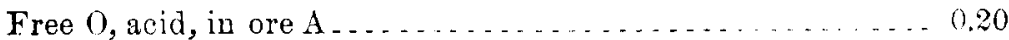
"
“ 13
" " in ash of Coke
"O, basic, in limestone 
Assume 360 kilos. of good coke at $10 \%$ of ash, a quantity judged sufficient for " a charge" or "lit de fusion," taken to be $=880$ kilos. stone and ore. This gives 36 kilos. of ash corresponding to 6.96

$36 \times \frac{100}{100}=2.50$ free oxygen of acid in the ash.

Let $\mathrm{m}$ be the weight of ore $A$ to be used, in kilogrammes.

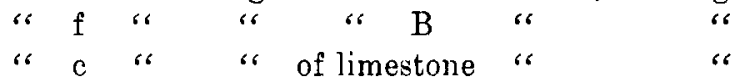

Then: 'The total free oxygen acid $=0.20 \mathrm{~m}+11.61 \mathrm{f}+2.50$.

'Total free oxygen, basic $=14.78 \mathrm{c}$, and since we want to obtain a bibasic slag, that is one in which oxygen, acid=oxygen, basic.

$0.20 \mathrm{~m}+11.61 \mathrm{f}+2.50=14 . .8 \mathrm{c}$, but we have also the equation of condition, total charge: $f+m+c=880$; we have then

$$
\overbrace{\text { Ore. }} \underset{\text { Stone. }}{\text {. }}
$$

two equations containing three unknown quantities. Eliminating $c$ between the two we come to the final equation:

$14.98 \mathrm{~m}+26.39 \mathrm{f}=13003.90$, an equation which is indeterminate, as it should be, since the proportions of ore $A$ and ore $B$, within the above limits, are evidently optional. Assuming for $\mathrm{m}$ certain values we find:

$$
\begin{array}{lll}
\mathrm{m}=50 & \mathrm{f}=464.50 & \mathrm{c}=365.50 \\
\mathrm{~m}=100 & \mathrm{f}=436.00 & \mathrm{c}=344.00 \\
\mathrm{~m}=200 & \mathrm{f}=379.25 & \mathrm{c}=300.75 \\
\mathrm{~m}=300 & \mathrm{f}=322.45 & \mathrm{c}=257.55
\end{array}
$$

and the charges will be :

Ore A ....... 50. $\} 514.50$ kilos. Or such others based on Ore B.........464.50\}

Limestone................ 365.50 ،

Coke 360.00 the other values of $\mathrm{m}$, f, c. Coke always $=360$ kilos.

The ores had about $35 \%$ metallic iron, hence $514.50 \mathrm{kilos}$. of ore would yield $514.50 \times 0.35=180$, iron, and taking the first solution, the relative proportions of the different materials in one charge for one of iron must be:

Ore 2.85

Stone $-2.03\}$ for $m=50$

Coke 2.00

Adopting the first solution let us calculate the composition of the slag and verify its bibasic character. 


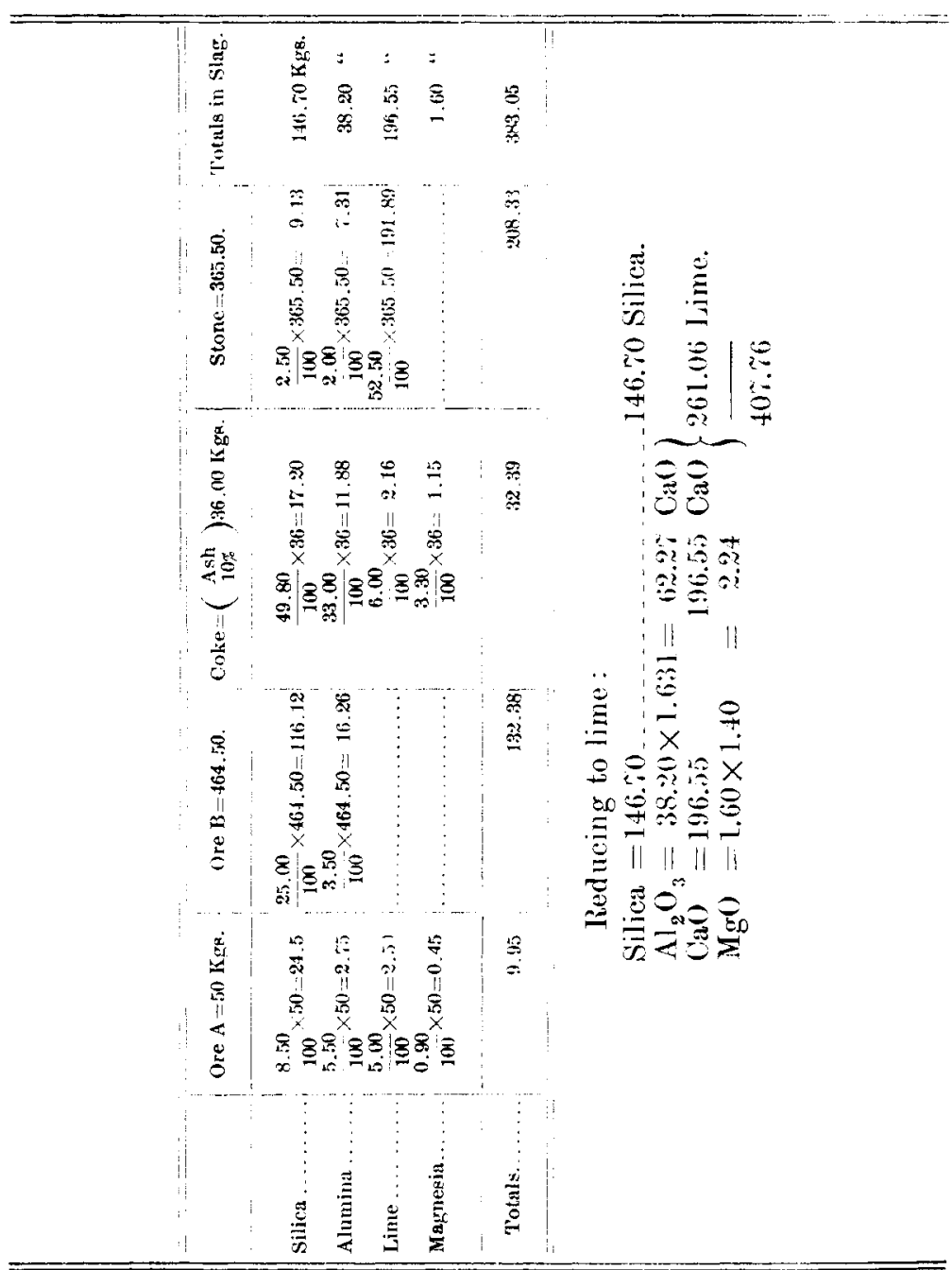

Reducing to a percentage, we find:

$\mathrm{SiO}_{2}=35.90 \quad$ The type, exactly bibasic, has the $\mathrm{SiO}_{2}=34.88$ $\mathrm{CaO}^{2}=64.10 \quad$ composition $\quad, \mathrm{CHO}^{2}=65.12$ 100.00 
The slag is practically a bibasic slag, as closely as possible using two decimals or only one, as in the analyses.

Let us calculate this same slag by the method of reduction to lime, adopting the same data and two indeterminate quantities of the ores $\mathrm{A}$ and $\mathrm{B}$.

\section{Ore A:}

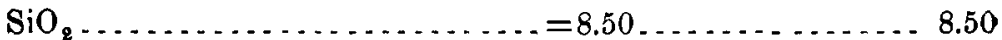

$\mathrm{Al}_{2} \mathrm{O}_{3} \ldots \ldots \ldots \ldots \ldots \ldots$
$\mathrm{CaO} \ldots \ldots \ldots \ldots \ldots$

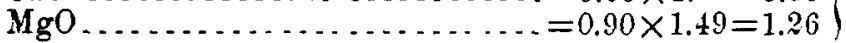

The saturation for a bibasic slag is $0.538 \mathrm{SiO}_{2}$ for 1 lime. 15.21 lime will take then : $15.21 \times 0.53=8.18 \mathrm{SiO}_{2}$, leaving 0.32 to $0.33 \%$ free silica to be saturated for 1 of ore.

Ore $B$ :

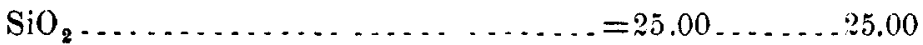

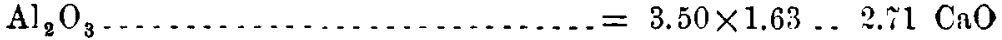

$5 \sim 1 \mathrm{CaO}$ will saturate $3.0 \mathrm{i} \mathrm{SiO}_{2}$, leaving $21.93 \%$ freo silica for 1 of ore.

Ash of Coke $(10 \% \times 360=36$ Kilos. $)$

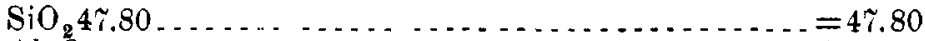

$\left.\mathrm{Al}_{2} \mathrm{O}_{3} \ldots \ldots \ldots \ldots \ldots \ldots \ldots=33 . \times 1.63+=53.59\right\}$

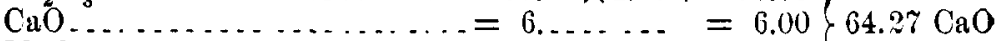

$\mathrm{MgO \ldots ...............}=3.20 \times 1.40=4.48$

$64.27 \mathrm{CaO}$ will saturate $64.27 \times 0.538=34.58$ silica, leaving in ash 13.22

13.22\% free silica. For 36 ash $\frac{1}{100} \times 36=4.76$ free silica.

Stone:

Silica $\ldots \ldots \ldots \ldots \ldots$ $\mathrm{Al}_{2} \mathrm{O}_{3} \ldots \ldots \ldots \ldots \ldots$
$\mathrm{CaO} \ldots \ldots \ldots \ldots$

1 silica takes up 1.858 lime to make a basic slag. Hence: 2.50 silica will take $2.50 \times 1.858$ lime $=4.65$ lime, leaving as free lime in the stone $51.11 \%$. 
Let $m$ be the amount of ore $A$ taken as before, $f$ that of ore $B$, $c$ that of stone. We have then:

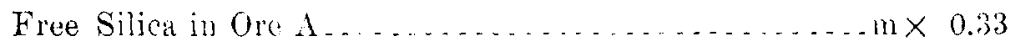

$" \quad " \quad$ in ash of Coal ...................... $\times 4 . i 6$

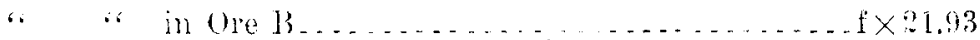

Total free silice in ores and coal : $0.33 \mathrm{~m}+21.93 \mathrm{f}+4.26$

Total free lime in stone:

$51.11 \mathrm{c}$

and since the free lime of the stone must saturate the free silica of the ores, stone and ash, at the rate of 0.538 silica for 1 of lime the $51.11 \mathrm{c}$ of free lime in stone will take up $51.11 \times 0.538 \mathrm{c}=3.50(3 \mathrm{c}$ of silica. We have then this equation free silica to saturate $0.33 \mathrm{~m}$ $+21.93 \mathrm{f}+4 . .76=2 i .50$ e silica saturated by stone. All the terms being expressed in silica, $\mathrm{SiO}_{2}$, if we multiply them all by $\frac{a}{15}$, which 15

does not change the equation, we shall have the relation of equality of the oxygen found previously by the other method as near as the difference of the numbers expressing the equivalents of silica formerly, and now (taking only one or two places of decimals) we have the differences appearing only in hundred ths as already observed. $\quad 0.18 \mathrm{~m}+11.68 \mathrm{f}+2.15=14.66 \mathrm{c}$, instead of $0.20 \mathrm{~m}+11.61 \mathrm{f}$ $+2.50=14.78 \mathrm{c}$. We have a second equation of condition the same as in the first method: $f+m+c=880$. By combining these two equations and taking $m=50,100$, ete., we shall find the same figures as already calculated or differing only in hundredths. 